\title{
Effect of Background Music for Attentive Concentration in Working
}

\author{
Sihun Park ${ }^{1,2}$, Chanbeom Kwak ${ }^{1,2}$, Woojae Han ${ }^{1,2,3}$ \\ ${ }^{1}$ Laboratory of Hearing and Technology, ${ }^{2}$ Division of Speech Pathology and Audiology, ${ }^{3}$ Research Institute of Audiology and Speech Pathology, \\ College of Natural Sciences, Hallym University, Chuncheon, Korea
}

Received: May 19, 2020

Revised: June 6, 2020

Accepted: June 6, 2020

\section{Correspondence:}

Woojae Han, PhD

Laboratory of Hearing and Technology,

Division of Speech Pathology and

Audiology, 8603 Natural Science

Building, Hallym University,

1 Hallymdaehak-gil, Chuncheon

24252, Korea

Tel: +82-33-248-2216

Fax: +82-33-256-3420

E-mail: woojaehan@hallym.ac.kr
Purpose: Recently, many young people have preferred to work in café than traditional library because the café is equipped with coffee, music, and cozy seats. When working in the café, whether listeners' attentive concentration could be affected by a kind of the background music needs to be investigated as the purpose of the present study. We also aimed to confirm the attentive concentration of listeners might be caused by their music inclination. Methods: A total of ninety young adults was randomly assigned as five kinds of background music [e.g., rhythm and blues (R\&B)/ballad, dance/rock, classic/jazz, fast beats, slow beats] and no music after responding to simple questions to ask their preference of music genre. While listening to the music, the subjects took an attentive concentration test, namely Frankfurter aufmerksamkeits-inventar (FAIR). The obtained data were analyzed by three subcategories of the FAIR test which consists of performance, quality, and continuity. Results: For the music genre, classic/jazz showed significantly higher continuity scores than R\&B/ballad, fast beats, and no music, which means that classic/jazz music of the café could help the workers maintain the attention. In the subgroup who listened to preferred music genre, their performance scores (i.e., selective attention) was significantly higher than that of the participants who being exposed to non-preferred music. Conclusion: Current results supports that music genre and individual music inclination may partially affect listener's ability of the attentive concentration when background music was presented in the café, although a further study to find certain possible causal factors with objective methods should be followed.

Key Words: Background music, Café music, Concentration, FAIR test, Music effect.

\section{INTRODUCTION}

커피가 현대인들의 삶의 일부로 자리매김함에 따라 카페는 복합 공간으로서 새로운 역할을 담당하고 있다. 최근 신문 기 사에 따르면 20 30대 젊은 계층에게 카페는 지인과 커피를 마 시면서 담소를 나누는 장소가 아닌 일을 하거나 공부를 하는 공간으로 인식되고 있으며, 코피스족(카페에서 업무를 보는 사 람), 카공족(카페에서 공부를 하는 사람) 등 신조어의 생성은 이러한 사회·문화적 트렌드를 반영한다(Lee, 2019). 일례로, 미 국 시카고의 한 카페에서는 무분별한 카공족과 코피스족의 증 가로 인해 수익 면에서 손해를 보는 영업주들이 "No laptops allowed'라는 문구를 벽면에 붙이고 카페 사용 시간을 2시간 이하로 제한하는 운동도 펼치고 있다(Kim, 2016).

왜 사람들은 카페에서 일 혹은 공부하는 것을 선호할까? 그

(c) This is an Open Access article distributed under the terms of the Creative Commons Attribution Non-Commercial License (https://creativecommons.org/licenses/by-nc/4.0) which permits unrestricted non-commercial use, distribution, and reproduction in any medium, provided the original work is properly cited.
이유를 여러 선행연구들의 결과들로 종합해 보면, 카페 내에 존재하는 적당량의 소음과 편안하고 자유로운 분위기는 창의 적인 인지수행능력을 향상시키고(Nielsen, 2015), 커피 속 카페 인은 집중력 향상에 도움을 준다(Arnold et al., 1994). 그중에 서도 카페 내의 적당한 소음, 즉 잔잔히 흐르는 음악은 젊은이 들이 숨소리 없는 고요하고 답답한 도서관에서 머무는 시간을 현저히 줄이는 결과를 가져왔다(Kang, 2013).

Rauscher et al.(1993)의 모차르트 효과 이론과 Thompson et al.(2001)의 각성 및 무드 가설에 근거하여, 음악 청취 시 청자 의 각성 상태 및 정서에 따른 집중력의 변화에 대한 관심은 음 악 청취와 집중력 간의 유의미한 관계를 분석하는 연구들로 구 체화되었다. Jang \& Lee(2008)는 음악 장르가 청자의 집중력 에 미치는 영향을 분석하기 위해 연구 대상자들을 클래식 음 악, 바이노럴비트음, 가요를 듣는 세 개의 하위 그룹들로 나누 어 뇌전도(electroencephalogram)를 적용하여 측정된 뇌파 집 중 지표 간 차이를 비교하였다. 그 결과 바이노럴비트음을 들 은 그룹이 가장 높은 집중력을 나타내어, 적당량의 리듬감이 
지속될 때 청자가 집중력을 잘 유지할 수 있다는 결론을 도출 하였다. 음악 청취가 중학생들의 주의집중력에 미치는 영향에 대해 알아본 Kang(2013)의 연구에서는 전경음악 혹은 배경음 악에 노출된 그룹들과 음악을 듣지 않은 그룹의 주의집중력을 프랑크푸르트 주의집중력검사(Frankfruter aufmerksamkeitsinventar, FAIR)를 적용하여 측정하였고, 배경음악을 들은 그 룹에서 자기 통제력이 가장 높게 나타났다. 즉, 음악이 존재하 되 매우 적극적인 청취를 유도하는 전경음악보다는 무의식적으 로 청자들을 자극하는 배경음악이 학생들의 집중력에 긍정적 인 영향을 줄 수 있었다. 이러한 결과는 Beak \& Lee(2016)의 연구에서도 동일하게 분석되었다. 빠른 음악 혹은 느린 음악에 노출된 그룹과 음악에 노출되지 않은 총 세 그룹 간의 주의집 중력을 FAIR 검사의 결과로 비교하였을 때, 느린 음악을 들은 그룹에서 평균적인 주의집중력의 크기가 가장 높게 측정되었 다. 따라서 연구자들은 배경음악이 존재하지만 빠르지 않은 음 악에 노출될 때 청자의 주의집중력에 긍정적인 효과를 나타낸 다고 결론 지었다. 그러나 힙합과 클래식 음악에 노출되는 동안 에 TOEFL 시험을 실시한 Tze \& Chou(2010) 연구에서는 오히 려 음악을 듣지 않고 시험을 시행한 그룹에서 가장 높은 TOEFL 점수를 나타내어 배경음악의 존재가 오히려 청자의 선 택적 주의집중력을 떨어뜨린다는 상반된 결론을 보여주었다. 이 러한 선행연구들 간 다소 상이한 결과들은 2 3개의 국한된 음 악 장르에서 주의집중력을 측정하였기에 유의미하지만 단편적 인 결론을 내렸다는 한계가 있다.

일반적으로 각성은 음악의 고저, 빠르기, 강도에 반응하는 자율신경계의 생리적인 각성과 인지적 반응으로 인한 정서적 각성으로 구분할 수 있다(Schäfer \& Sedlmeier, 2009a). 더불 어 음악의 음향학적 특성은 청자의 각성과 감정에 영향을 미쳐 집중력의 변화를 일으킬 수 있다(Kang, 2013). 즉, 음악에 대한 정서를 청자의 각성 및 감정과 결부하여 네 가지 유형으로 분 석해 볼 수 있다(Punkanen et al., 2011). 예를 들어 높은 각성 과 부정적 감정의 음악은 분노, 짜증, 공포의 반응을, 낮은 각성 과 부정적 감정의 음악은 우울감의 반응을 이끌며, 높은 각성 과 긍정적 감정의 음악은 즐겁고 신나는 반응을, 낮은 각성과 긍정적 감정의 음악은 평화로운 반응을 이끌어 낸다. 이러한 음 악 청취에 따른 개인의 정서적 상태를 고려하여, 배경음악이 청 자의 특정 기능의 수행에 긍정적/부정적 영향을 주는지 고려할 필요가 있지만, 안타깝게도 앞서 언급한 선행연구들에서는 음 악 장르를 구체적으로 세분화하지 못하였거나, 청자의 선호 음 악을 고려할 때 개인적인 성향을 조사하지 못했거나, 개인별 학 습 성향을 고려하지 못한 채 성급한 결론을 도출하였다. 그러 므로 본 연구에서는 음악의 주파수적 특성이나 개개인의 선호 음악 청취 여부들을 포함하고 생리적 각성의 구성 요소인 음악
의 빠르기, 가사 유무, 음향학적 특성 등을 고려하여 음악 장르 를 보다 구체적으로 세분화하고 이러한 배경음악의 특징에 따 른 청자들의 주의집중력의 차이를 보다 다각적으로 분석해 볼 필요가 있다.

본 연구의 목적은 선행연구들의 한계를 극복하면서 음악 장 르에 따른 청자의 주의집중력의 변화를 확인하기 위해, 독일의 Moosbrugger \& Oehlschläger(1996)에 의해 개발된 FAIR 검 사를 활용하였다. FAIR 검사는 집중력에 대한 선택적 주의력, 자기 통제력, 지속적 주의력 기능을 모두 측정할 수 있는 도구 이며, 특히 주의(attention)의 개념이 선택적 주의력에 편중되었 던 기존의 주의집중력의 개념을 자기 통제력, 각성, 정신력에 의 한 주의 지속성의 개념까지 포함하여 보다 다각적이며 정량화 된 구체적인 방식으로 사용자의 주의집중력 정도를 측정할 수 있는 장점이 있다(Oh, 2002). 최근 FAIR 검사는 조도와 색 온 도 변화에 따른 주의집중력을 분석한 연구(Lee et al., 2016), 자 율성을 매개로 청소년 비행에 영향을 미치는 기질 및 주의력 결 핍 연구(Oh, 2018), 색 자극에 따른 생리적 반응과 주의집중력 관계 연구(Lee et al., 2014) 등에 적용되면서 연구자들에게 집중 력 측정 도구로써 신뢰성을 검증받았다. 본 연구에서는 음악 장 르의 음향학적 특성이 청자의 주의집중력의 각 구성 요소에 미 치는 영향을 확인하기 위해 FAIR 검사 결과를 능력지수, 통제 지수, 지속성지수로 세분화하여 확인하였고, 청자의 선호 음악 노출 시 주의집중력에 미치는 영향을 구체적으로 분석하였다.

\section{MATERIALS AND METHODS}

\section{연구 대상}

본 연구에서는 대학교에 재학 중인 20대의 남성 40명과 여성 50명, 총 90명(평균 연령: 22.11세, 연령 범위: 19 28세)을 자발 적으로 실험에 참여하도록 독려하였다. 실험 전 연구 대상자들 의 이과적 질환 및 청력 손실 여부를 선별하기 위해, 고막운동 도검사와 순음청력검사를 실시하였다. 모든 대상자는 고막운 동도검사에서 $\mathrm{A}$ 형의 정상 기능을 보였으며, 주파수별 청력역치 는 $15 \mathrm{~dB} \mathrm{HL}$ 이하로 모두 정상 청력 범위에 해당하였다. 하위 실험 그룹의 무작위 할당을 위해, 연구 대상자에게 음악 장르 와 각 장르의 선호 정도를 10점 척도로 구성된 3가지 문항들을 통하여 간단히 답변하는 방식으로 설문하였다. 또한 실험 전 FAIR 검사 도구를 그림 연결 게임으로 설명하여 실험의 핵심 적인 목적을 은폐하되(Kang, 2013), 연구자는 연구 대상자에게 검사 수행 방법을 자세히 설명한 후 검사 설명서에 제시된 연습 문항을 풀어 보도록 요구하였다. 


\section{주의집중력검사 도구(Korean-FAIR)}

주의집중력 정도를 측정할 수 있는 FAIR 검사는 $\mathrm{Oh}(2002)$ 에 의해 한국어로 번역된 후 표준화 과정을 거쳤다. KoreanFAIR 검사는 타입 I과 타입 II로 구성되었고, 각 타입은 여러 개의 동그라미, 네모, 점들로 겹쳐진 아이템이 총 320개(16열 $\times$ 20행)씩 포함되어 있다. 검사 시간 동안 연구 대상자는 각 열의 가장 왼쪽에서 제일 오른쪽으로 하나의 선을 그어 연결하면서 중간중간에 숨어 있는 '동그라미 안에 세 개의 점' '네모 안에 두 개의 점이 있는 아이템만을 톱니 모양으로 표시하는 방식이다.

총점 $\mathrm{T}$ 는 3 분 동안 몇 개의 아이템을 작업했는지 총량을 수 치화한다. 작업한 아이템들 중에서 규정된 표시의 원칙을 벗어 나 선을 그린 '선 그리기 오류'는 error of line drawing으로 표 기한다. 목표 아이템의 선 그리기를 간과한 '간과 오류'는 error of overlooking으로 표시하며, 목표 아이템이 아닌 곳에 표기한 '오답'은 commit an error로 표시하여 각각의 수를 작성란에 기 록한다. FAIR 검사의 각 세부 영역은 Table 1 과 같은 산출 방식 에 따라 능력지수(performance value), 통제지수(quality value), 지속성지수(continuity value)로 구분한다. 능력지수는 사 용자의 선택적 주의 집중 능력을 측정하는 점수로서, 검사 시 간 동안 올바르게 작업한 검사 아이템의 양을 의미한다. 통제 지수는 능력지수를 응답한 아이템의 총량으로 나눈 값으로써 사용자의 자기 통제력을 의미한다. 지속성지수는 능력지수와 통제지수를 곱한 것으로 검사 시간 동안의 유지된 주의력 혹은 주의력의 지속 정도를 의미한다.

Table 1. Three subcategories of the Frankfurter aufmerksamkeitsinventar test to measure amount of attentive concentration and their scoring methods

\begin{tabular}{clc}
\hline Subcategory & \multicolumn{1}{c}{ Definition } & Scoring method \\
\hline $\mathrm{P}$ & Selective attention ability & $\left(\mathrm{T}-\mathrm{E}_{\mathrm{L}}\right)-2\left(\mathrm{E}_{\mathrm{o}}+\mathrm{E}_{\mathrm{c}}\right)$ \\
$\mathrm{Q}$ & Self-control ability & $\mathrm{P} \div \mathrm{T}$ \\
$\mathrm{C}$ & Maintaining ability & $\mathrm{P} \times \mathrm{Q}$ \\
& of attention & \\
\hline
\end{tabular}

P: performance value, Q: quality value, C: continuity value, T: total worked items, $\mathrm{E}_{\mathrm{L}}$ : error of line drawing, $\mathrm{E}_{\mathrm{o}}$ : error of overlooking, $\mathrm{E}_{\mathrm{c}}$ : commit an error

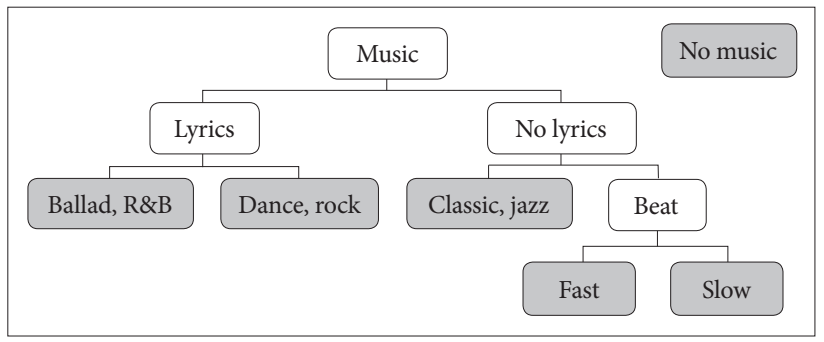

Figure 1. A classification as acoustic characteristics and six background music conditions used in the present study including no music condition, i.e., six gray blocks. R\&B: rhythm and blues.

\section{음악 장르 구분 및 선정 음악의 음향적 특성}

음악 장르는 음악의 일반적인 특성에 따라 Figure 1과 같이 총 6가지로 분류하였다. 먼저 실험 그룹을 음악에 노출과 비노 출로 구분하고(music vs. no music), 배경음악에 노출 시 가사가 있는 음악과 가사가 없는 음악(lyrics vs. no lyrics)으로 구분하 였다. 가사가 있는 음악은 발라드와 rhythm and blues (R\&B)를 하나의 그룹으로, 댄스와 록을 다른 그룹으로 구분하였다. 반 면 가사가 없는 음악은 클래식과 재즈를 하나의 그룹으로, 반 복적인 비트음을 다른 그룹으로 구분하였고, 다시 비트음은 빠 른 비트와 느린 비트로 세분화하였다.

무음악을 포함하여 총 6 개의 음악 장르로 구분한 후, 각 장 르를 대표할 만한 음악을 선정하였다. 배경음악의 선정은 전경 음악과 반대로 음악에 따른 청자의 각성 정도가 낮으나 어느 정도 업무 수행의 효율성을 높여줄 수 있는 음악을 선택하였다 (Kang, 2013). 더불어 새롭지 않고 익숙한 음악을 선정하되, 각성 정도가 너무 높은 최신 유행하는 음악은 제외하였다(Kang, 2013). 이러한 기준들을 고려하여 발표된 지 10년 이상 된 K-Pop 을 중심으로 멜로디가 없는 비트음을 제외하고 장르에 따라 각 각 5곡씩 선정하였다. 빠른 비트음과 느린 비트음은 Mixmeister BPM Analyzer (MixMeister Technology, Fort Lauderdale, FL, USA)로 구현된 beats per minute (BPM) 160과 70의 드럼 비트음을 사용하였다.

선정된 음악은 음향 분석 프로그램인 Praat (Boersma \& Weenink, 2013)을 사용하여 강도, 주파수, 포먼트를 측정하였 고, mixmeister BPM analyzer로 음악의 빠르기인 BPM을 분 석하였다. 본 연구에 사용된 배경음악의 구체적인 음향학적 특 징은 Table 2에 제시하였다.

\section{연구 절차}

Figure 1 의 절차와 같이 총 6 개의 장르로 구분된 배경음악들 의 하위 그룹은 각각 15 명씩의 연구 대상자가 무작위로 할당되 었다. 카페 배경음악의 제시 상황과 유사하도록, 조용한 방에서 너무 크지 않은 평균 40 50 dB (A)의 소리 강도(Biederman \& Pattison, 2014)에서 앞- 뒤·측면으로 4개의 스피커(CS-15 Model, Bobson Co., Shanghai, China)에서 배경음악을 제시 하였다. 그룹별로 동일한 방 환경에서 한 번에 실험을 진행하였 으며, 그룹 간 자리 배치를 동일하게 조작하였다. 또한 연구 대 상자들에게 반향음은 음악의 리듬을 틀리게 하여 결과에 영향 을 미칠 수 있으므로(Hyun et al., 2009), 벽에서 약 $1 \mathrm{~m}$ 가량 떨어진 곳에서 자리를 고정 배치하였고 대상자들은 각자 원하 는 좌석에서 FAIR 검사를 실시하였다.

각 그룹별로 선정된 배경음악이 나오도록 통제된 상황에서 음악 선호도 조사 설문을 가장 먼저 실시하고, FAIR 주의집중 
Table 2. Summary of acoustic features for the five music genres used in the study

\begin{tabular}{|c|c|c|c|c|c|c|c|c|}
\hline \multirow{2}{*}{ Genre } & \multirow{2}{*}{ Intensity (dB) } & \multirow{2}{*}{ Pitch (Hz) } & \multicolumn{5}{|c|}{ Formants $(\mathrm{Hz})$} & \multirow{2}{*}{ BPM } \\
\hline & & & $\mathrm{F} 1$ & F2 & F3 & $\mathrm{F} 4$ & F5 & \\
\hline \multirow[t]{2}{*}{ Ballad/R\&B } & 81.55 & 166.26 & 176.49 & $1,782.97$ & $2,947.32$ & $3,982.84$ & $4,787.04$ & 121.85 \\
\hline & $(0.83)$ & $(50.94)$ & $(45.71)$ & $(40.78)$ & $(60.98)$ & $(82.47)$ & (130.98) & (14.18) \\
\hline \multirow[t]{2}{*}{ Dance/rock } & 83.27 & 197.83 & 894.49 & $1,962.80$ & $3,062.02$ & $4,076.79$ & $4,829.93$ & 119.41 \\
\hline & $(1.04)$ & $(75.21)$ & $(54.33)$ & $(76.90)$ & (79.04) & $(55.08)$ & $(67.08)$ & $(5.42)$ \\
\hline \multirow[t]{2}{*}{ Classic/jazz } & 73.28 & 76.02 & 592.77 & $1,458.47$ & $2,422.51$ & $3,619.66$ & $4,584.73$ & 130.92 \\
\hline & (5.29) & $(24.00)$ & (105.97) & $(237.61)$ & (244.95) & $(86.13)$ & (93.59) & $(14.55)$ \\
\hline Slow beats & 73.48 & 160.60 & $1,276.19$ & $2,291.25$ & $3,435.80$ & $4,368.34$ & $4,936.49$ & 70.00 \\
\hline Fast beats & 78.31 & 218.13 & $1,303.42$ & $2,408.08$ & $3,423.35$ & $4,432.41$ & $5,016.65$ & 160.00 \\
\hline
\end{tabular}

Average and standard deviation of each component for the music genre when analyzed in Praat software. BPM: beats per minute, R\&B: rhythm and blues

력에 대한 검사 설명, 타입 I 검사 및 타입 II 검사 진행의 절차 는 그룹 간 모두 동일하였다. FAIR 검사 시간은 각 타입당 3 분 씩 총 6분이 소요되었다. 따라서 연구 대상자는 FAIR 검사 시 간 동안 약 2 3곡의 음악에 노출되었고, 연구 대상자는 검사 설명 및 음악 선호도 설문지 작성 중에도 지속적으로 음악에 노출되었다. 연구 대상자당 실험 시간은 총 20 분이 소요되었다.

\section{통계 분석}

90명의 연구 대상자의 능력지수, 통제지수, 지속성지수를 각 각 FAIR 검사의 계산에 의거하여 산출하고, 이 중 능력지수, 통제지수, 지속성지수가 9등급의 표준점수 중 1 2등급인 연구 대상자들의 결과는 대상자 자체의 주의력 결핍으로 인한 데이 터 오염으로 간주하여(Oh, 2002) 통계 분석에서 제외하였다. 그룹당 1 명 혹은 많게는 4명이 제외되어 최종 80 명의 대상자 를 데이터로 정리하였다.

6 개의 음악 장르에 노출된 그룹들 각각의 능력지수, 통제지 수, 지속성지수의 검사 결과를 통계프로그램(SPSS, ver. 23.0, IBM Corp., Armonk, NY, USA)을 이용하여 일원분산분석 (one-way analysis of variance)을 실시하고 통계적 유의성을 확인하였다. 필요 시 Tukey 사후검정(post-hoc comparison)을 적용하여 그룹 간 유의성을 확인하였다. 또한 청자의 선호 음악 노출 여부에 따라 선호 음악을 들은 그룹과 선호하지 않은 음 악을 들은 그룹, 그리고 무음악의 대조 그룹으로 구분하여 세 그룹 각각의 능력지수, 통제지수, 지속성지수 결과를 SPSS 프 로그램을 활용하여 일원분산분석과 사후검정을 실시하고 유의 성을 검증하였다. 본 연구에서 사용한 통계적 유의성은 $p<$ 0.05 였다.

\section{RESULTS}

\section{음악 장르에 따른 주의집중력의 차이}

Figure $2 \mathrm{~A}$ 를 살펴보면 배경음악 장르 중 클래식/재즈를 들 은 그룹의 능력지수 평균은 488.36[standard deviation (SD): 48.63]으로 가장 높았고, 댄스/록을 들은 그룹이 459.57(SD: 62.54), 느린 비트음을 들은 그룹이 448.92(SD: 64.83), 발라드/ $\mathrm{R} \& \mathrm{~B}$ 의 그룹이 437.71(SD: 80.95), 빠른 비트음을 들은 그룹은 434.73(SD: 75.89)의 순서로 능력지수가 낮아졌다. 배경음악에 노출이 없었던 무음악 그룹의 능력지수의 평균은 419.71 (SD: 51.89)로 가장 낮게 나타났다. 그러나 배경음악의 장르 간 능력 지수의 차이는 통계적으로 유의미하지 않았다 $[\mathrm{F}(5,79)=1.876$, $p=0.109]$.

음악의 장르에 따른 통제지수의 차이는 느린 비트음에 노출 된 그룹의 평균이 0.9646(SD: 0.023)으로 가장 높았고, 그 다음 으로 발라드/R\&B를 들은 그룹이 0.9643(SD: 0.022)으로 나타 났다. 빠른 비트음에 노출된 그룹은 0.9591(SD: 0.031), 클래식/ 재즈를 들은 그룹은 0.9586(SD: 0.023)으로 그 다음 순위를 기 록했다. 댄스/록을 들은 그룹과 무음악 그룹의 통제지수가 각 각 0.9579(SD: 0.024)와 0.9579(SD: 0.025)로 가장 낮았다 (Figure 2B). 음악 장르에 따른 통제지수의 차이 역시 통계적으 로 유의미하지 않았다 $[\mathrm{F}(5,79)=0.219, p=0.953]$.

Figure $2 \mathrm{C}$ 는 음악의 장르에 따른 그룹 간 지속성지수의 차 이를 비교하였다. 클래식/재즈를 들은 그룹의 평균이 502.37 (SD: 55.07)로 가장 높게 나타났고, 댄스/록 그룹이 440.31(SD: 64.76)로 두 번째로 높게 나타났다. 그 다음으로 느린 비트음의 그룹이 433.37(SD: 64.57), 무음악 그룹이 429.80(SD: 53.30), 발 라드/R\&B를 들은 그룹이 422.00(SD: 80.79)의 순서로 지속성 지수가 점차 낮아졌다. 빠른 비트음에 노출된 그룹이 381.64 (SD: 44.97)로 가장 낮은 지속성지수를 보여주었다. 통계적으로 그룹 간 지속성지수는 유의한 차이를 보여주었다 $[\mathrm{F}(5,74)=$ 

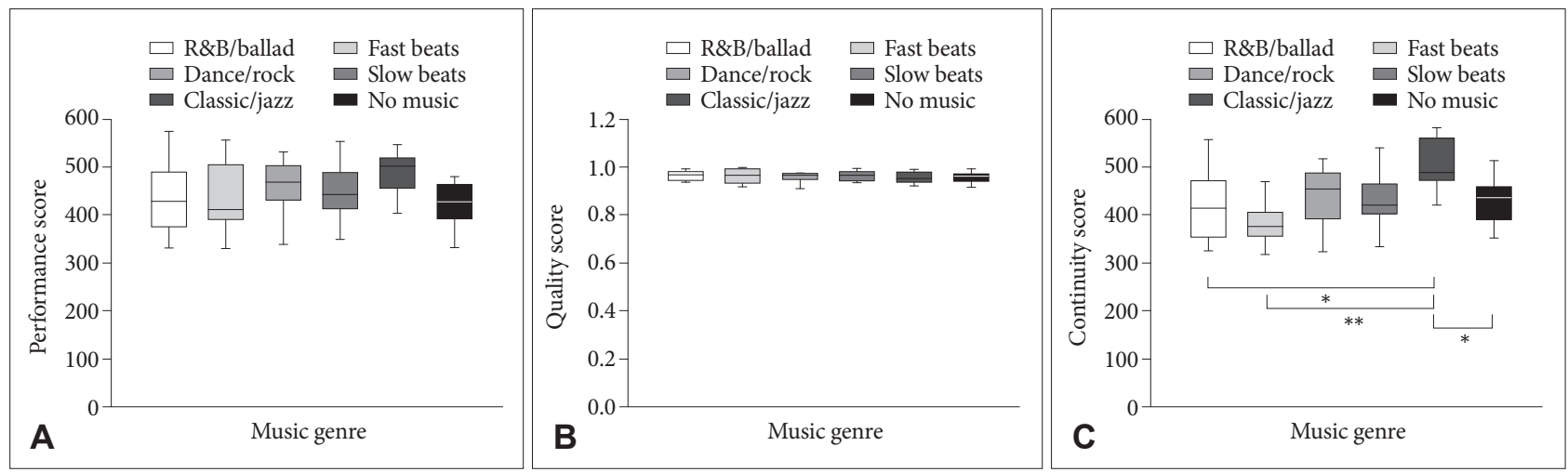

Figure 2. Comparison of group average for the Frankfurter aufmerksamkeits-inventar test as a function of music genre: performance (A), quality (B), continuity (C) scores. ${ }^{*} p<0.05,{ }^{* *} p<0.01$.
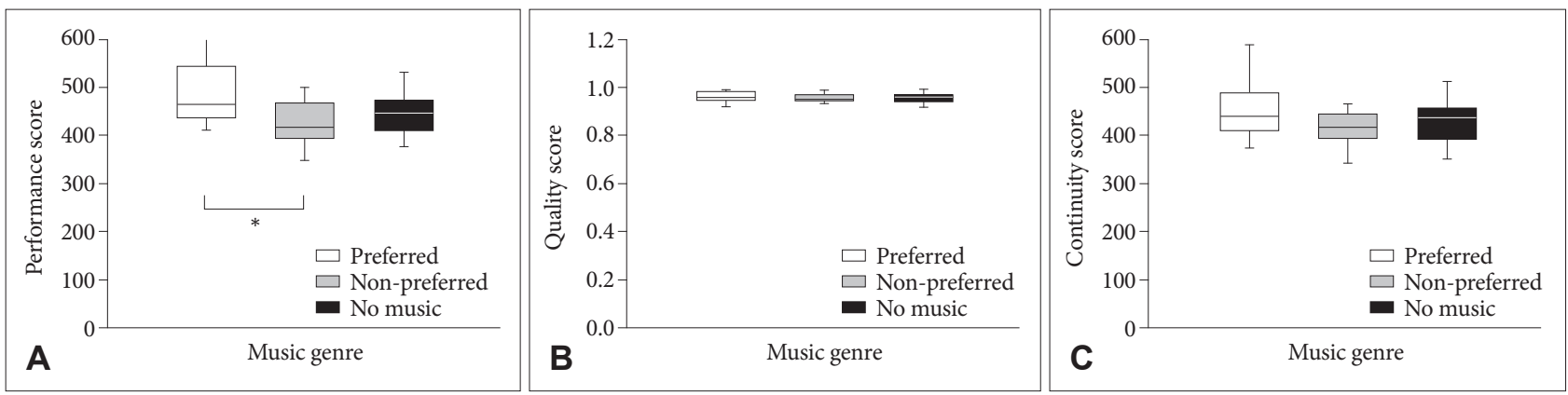

Figure 3. Comparison of group average for Frankfurter aufmerksamkeits-inventar test as music inclination: performance (A), quality (B), continuity $(\mathrm{C})$ scores. ${ }^{*} p<0.05$.

5.059, $p<0.001]$. 사후 분석 결과 클래식 장르를 배경음악으 로 들었을 때 발라드/R\&B ( $p=0.013)$, 빠른 비트음 $(p<$ $0.001)$, 무음악 배경 $(p=0.032)$ 에서 보다 청자의 지속성지수가 유의하게 높았다.

\section{음악 선호도에 따른 청자의 주의집중력의 차이}

음악 선호도 설문 결과를 바탕으로 가장 선호하는 음악과 노출 음악이 일치하는 경우를 선호 그룹으로, 가장 비선호하는 음악과 노출 음악이 일치하는 경우를 비선호 그룹으로 분류하 였다. 또한 무음악 그룹을 대조군으로 설정하였다. 예상한 대로 선호 그룹의 능력지수의 평균은 489.50(SD: 71.10)으로 가장 높 았고, 다음으로 배경음악이 없었던 무음악 그룹이 448.29(SD: 50.99)로 두 번째로 높았으며, 비선호 음악에 노출된 그룹이 424.50(SD: 50.12)으로 가장 낮게 나타났다(Figure 3A). 이는 또한 통계적으로 그룹 간 유의한 차이를 보여주었다 $[\mathrm{F}(2,39)=$ 4.467, $p=0.018]$. 사후 분석 결과 청자가 선호하는 음악과 배경 음악이 같은 환경에서 비선호하는 배경음악의 노출 $(p=0.014)$ 에서보다 능력지수가 유의미하게 높았다.

선호 음악에 노출된 그룹의 통제지수 평균은 0.9586(SD: 0.027)으로 가장 높았고, 다음으로 무음악 그룹이 0.9579(SD: 0.025)로 두 번째로 높았다. 반면, 비선호 음악에 노출된 그룹의
통제지수는 0.9571(SD: 0.021)로 가장 낮게 나타났다(Figure 3B). 그러나 통제지수의 그룹 간 차이는 통계적으로 유의미하게 나타나지 않았다 $[\mathrm{F}(2,41)=0.012, p=0.988]$.

한편 지속성지수에서 선호 음악에 노출된 그룹의 평균은 455.14(SD: 69.73)로 가장 높게 나타났다. 다음으로 무음악 집 단이 429.80(SD: 53.30)으로 두 번째로 높았으며, 비선호 음악 에 노출된 그룹의 지속성지수는 414.85(SD: 42.89)로 가장 낮 았다(Figure 3 C). 지속성지수의 그룹 간 차이는 통계적으로 유 의미하지 않았다 $[\mathrm{F}(2,41)=1.826, p=0.175]$.

\section{DISCUSSIONS}

본 연구는 배경음악의 장르가 청자의 주의집중력에 미치는 영향과 개인의 선호 음악 청취에 따른 주의집중력의 차이를 확 인하기 위해, 무작위로 할당된 15명씩의 청자들이 6 개의 배경 음악을 들으면서 FAIR 검사를 실시한 후 능력지수, 통제지수, 지속성지수로 세분화하여 분석하였다.

\section{음악 장르에 따른 청자의 주의집중력 변화}

음악 장르에 따른 주의집중력의 각 구성 요소에 미치는 영향 을 살펴본 결과, 클래식/재즈의 배경음악을 들은 그룹의 지속 
성지수가 다른 음악에 노출된 그룹과 비교 시 유의미하게 높았 다. 능력지수와 통제지수는 표면적 행동 차원에서 볼 때 개인의 작업 방식과 관련이 있는 반면, 지속성지수는 선택 주의력과 인지적 자기 통제력이 고려된 기능으로서 상대적으로 인지 하 위 능력인 능력지수와 인지 상위 능력인 통제지수를 통합하는 지속적 능력에 해당한다. 즉, 지속성지수는 집중력의 통합과 복 잡성을 설명해 줄 수 있다(Oh, 2002). 클래식/재즈의 배경음악 으로 사용한 예로 Rauscher et al.(1993)의 연구에서는 모차르 트 Sonata in D major for two pianos k.448의 배경음악 상황 에서 공간 추론능력과 집중력이 유의미하게 상승하였다. 후속 연구인 Piano concerto no. 23 in A major를 배경음악으로 사 용한 Wilson \& Brown(1997)의 연구와 슈베르트의 Fantasia for piano and 4 hands in F minor를 배경음악으로 활용한 Nantais (1997)의 연구에서도 유사하게 청자의 수행능력이 향상되었다. 따라서 선행연구들과 본 연구의 결과는 공통적으로 클래식의 배경음악 청취 상황에서 업무 시 청자의 집중력의 지속성이 잘 유지될 수 있었다.

왜 클래식 등의 가사가 없는 잔잔한 음악을 들을 때 청자의 집중력이 의미 있게 지속되었을까? 본 연구에서 사용한 음원에 대하여 음향학적 특징을 분석해 보면 클래식/재즈에서 사용한 음원이 타 음악 장르에 비하여 평균적인 주파수가 가장 낮았다 (Table 2). 평균 주파수가 낮았던 클래식/재즈의 배경음악에 노 출된 청자 그룹의 높은 지속성지수는 Kim et al.(2004)의 결과 에서도 일부 일치하였다. 즉, 저주파수의 음을 발생시켜 집중력 을 유지 혹은 향상시키는 임상연구인 선행연구에서는 평균 주 파수가 낮은 클래식/재즈 장르의 배경음악 상황에서 청자는 집 중력을 최대한 지속적으로 발휘할 수 있었다. 반면, 지속성지수 에서 가장 낮은 점수를 보였던 빠른 비트음의 음향학적 특징을 분석해 볼 때 BPM과 평균 주파수가 가장 높았다(Table 2). 음 악에 따른 운전자의 운전 집중 행동 특성을 살펴본 Pêcher et al.(2009)의 연구에서는 높은 주파수와 빠른 템포 음의 음악이 운전자의 측면 제어를 악화시키고, 궁극적으로 주의 집중을 분 산시켰다. 이는 본 연구에서 사용한 배경음악의 음향학적 특징 과 주의집중력 결과와도 매우 일치하며, 높은 평균 주파수와 $\mathrm{BPM}$ 의 음향학적 특징을 갖는 빠른 비트음의 배경음악 상황에 서는 청자가 집중력을 지속적으로 발휘하기 어렵다.

Schäfer \& Sedlmeier(2009a)에 따르면 각성은 음악의 구조 적 요소에 의해 반응하는 자율신경계의 생리적 각성과 음악에 대한 정서, 인지적 반응으로 인한 정서적 각성으로 나뉜다. 클 래식/재즈 음악의 포먼트 중 F1과 F2는 평균적으로 다른 장르 의 음악과 비교할 때 가장 낮은 반면, 빠른 비트음의 경우 F1과 F2가 다른 장르의 음악과 비교할 때 가장 높았다. Goudbeek et al.(2009)의 연구에서 F1과 F2의 포먼트주파수는 감정 측면
에서 크게 영향을 받으며, 발화 시의 각성은 높은 F1과 F2의 결과와 상응하였다. 즉, 서론에서 언급하였듯이 음악이 가지고 있는 음향학적 특성은 청자의 각성과 감정에 영향을 미쳐 집중 력의 변화를 일으킬 수 있다. 이를 다시 본 연구의 결과에 적용 해 보면 클래식/재즈의 배경음악은 낮은 F1과 F2 포먼트주파 수가 청자로 하여금 낮은 생리적 각성을 불러일으키며, 음악 청 취 시 두뇌 활동이 개입할 때 음악이 현재 수행하고 있는 작업 의 하위 영역에 있는 배경음악의 역할을 적절히 수행한 것으로 분석된다(Kang, 2013). 배경음악은 인지적 작업 수행에 긍정적 인 영향을 미치기 때문에 클래식/재즈의 배경음악 상황에서 연 구 대상자들은 오랜 시간 FAIR 검사에서 집중력을 발휘할 수 있었다. 이와 달리, 빠른 비트음의 경우 높은 F1과 F2 포먼트주 파수가 청자로 하여금 높은 생리적 각성을 불러일으켰고, 음악 청취 시 두뇌 활동이 개입할 때 음악이 선택적 주의 집중을 받 는 전경 음악의 역할을 수행한 것으로 예측된다(Kang, 2013). 따라서 결과적으로 FAIR 검사보다 음악에 집중을 뺏겨 연구 대상자들은 FAIR 검사에 집중력을 오랜 시간 발휘할 수 없었 을 것으로 분석된다.

한편, Cho et al.(2015)은 빗소리 종류에 따른 스트레스 경감 효과를 살펴보았다. 연구자들은 한의학적 접근으로 간(肝)과 관련 있는 발음인 아음(牙ㅎㅂ)을 분석하였고, F3의 포먼트주파 수 대역폭이 큰 것을 바탕으로 스트레스가 경감되는 것을 확인 했다. 본 연구의 결과에 적용해 보면 클래식/재즈의 배경음악 에서 F3 포먼트주파수의 변화폭은 694.8로 다른 장르와 비교 시 가장 높았다. 이는 클래식/재즈 음악 상황에서 다른 음악 상 황에 비해 스트레스가 경감되는 효과를 기대할 수 있겠고, 연 구 대상자들의 경감된 스트레스는 주의 집중 지속성의 높은 점 수를 이끌었을 것으로 사료된다. 이와는 반대로, 빠른 비트음 에서는 변화가 없는 F3 포먼트주파수의 특성상 스트레스의 경 감 효과를 기대할 수 없었고, 오히려 낮은 주의 집중 지속성으 로 이어졌을 것이다. 다시 말해 본 연구에서 각 장르의 평균 주 파수와 포먼트를 비교 시, 클래식/재즈 음악의 주파수 대역이 가장 넓었고 이는 높은 주의 집중 지속력을 이끈 것으로 사료 된다. 그럼에도 배경음악의 장르에 따른 집중력 정도를 $\mathrm{TOEFL}$ 검사로 실시한 Tze \& Chou(2010)의 연구에서는 힙합 음악과 클래식 음악과 비교 시, 무음악 그룹이 가장 높은 점수를 기록 하여 배경음악이 오히려 주의집중력을 방해한다는 본 연구와 는 상이한 결과를 보여준다. 이는 주의집중력 검사 도구로 활용 되는 지능검사 혹은 FAIR 검사와는 달리 주된 목적이 집중력 검사가 아닌 영어 수행능력의 평가인 TOEFL로 적용하여 상 이한 결과를 이끈 것으로 사료된다.

왜 주어진 시간 안에 얼마나 많은 정보를 처리했는가를 확인 하는 지수인 능력지수와 주의의 정확성을 확인하는 통제지수 
에서는 배경음악 장르에 따른 유의미한 차이를 발견할 수 없었 을까? Speer(2011)는 배경음악, 말, 무음악의 세 가지 조건에서 주의집중훈련 검사로 선택적 주의집중력을 측정한 결과, 배경 음악 그룹이 가장 높은 점수를 보였다. Darrow et al.(2004)의 연구에서도 배경음악 그룹과 무음악 그룹의 비교 결과 배경음 악 그룹이 주의집중력 점수에서 높은 점수를 나타냈고 이러한 결과는 음악 전공과 비전공 그룹에서 모두 나타났다. 선행연구 에서는 주의집중력의 상승이라는 공통된 결론을 제공하였지 만, 주의 집중의 어느 요소가 높은 주의집중력으로 이끌었는지 에 대해서는 부재하여 본 연구의 결과와 직접적으로 비교하기 엔 다소 한계가 있지만, 주의 집중 요소 중에서도 지속성의 요 소가 배경음악 상황의 수행능력 상승을 이끈다는 것을 확인할 수 있었다. 안타깝게도 본 연구에서는 대조군인 무음악 그룹과 유의미한 차이를 확인할 수 없었다. 이는 Kang(2013)의 연구에 서도 배경음악 그룹과 무음악 그룹과 비교했을 때, 능력지수와 지속성지수에서 부분적으로만 유의미한 차이를 확인할 수 있 었다. 다만, 표면적 행동 차원에서 볼 때 능력지수와 통제지수 는 개인의 작업 방식과 관련이 있기에(Oh, 2002), 이러한 결과 는 집중력보다는 개인의 작업 방식의 차이일 가능성이 크다.

\section{청자의 선호 음악에 노출과 주의집중력}

개인별 선호 및 비선호 음악에 노출 시 주의집중력에 미치는 영향을 살펴본 결과, 선호하는 배경음악에서의 주의집중력 중 능력지수가 비선호 배경음악 상황보다 높았다. Mornhinweg (1992)의 연구에서는 선호 음악의 환경에서 스트레스가 감소되 는 의미 있는 결과를 보여주었다. 이에 음악 선호도 및 선택에 따라 스트레스가 감소될 수 있는 것이, 즉 스트레스의 감소로 인한 선택적 주의 집중능력이 선호된 배경음악에서의 능력지수 의 상승으로 이어지지 않았나 해석할 수 있다. 이와는 반대로 비선호 음악은 배경음악이 듣기 싫은 소리로 총칭되는 소음 (Ko et al., 2004)으로 개인적인 성향으로 간주되고 부정적 감정 의 요소와 복잡하게 연관되어 스트레스의 요인으로 작용했을 가능성이 있다. 또한 연구 대상자 입장에서 3 분이라는 제한된 검사 시간에 많은 양의 아이템을 정확하게 처리해야 하는 부담 감과 스트레스로 인해 양적 과부화가 일어난 것으로 보인다 (Lee \& Park, 1988). 이를 Schäfer \& Sedlmeier(2009a)가 주 장한 각성의 관점에서 보면, 스트레스가 높은 정서적 각성인 불 쾌한 감정에 관여하여 주의집중력을 떨어뜨린 것으로 볼 수 있 다. 이러한 원인이 비선호 음악 그룹의 낮은 능력지수 점수와 관련이 있을 것으로 분석될 수 있겠다.

안타깝게도 음악 선호도에 따른 통제지수와 지속성지수는 유의미한 차이를 확인할 수는 없었다. 음악 선호도와 기능에 대한 Schäfer \& Sedlmeier(2009b)의 연구에서 일반적으로 음
악의 특정 스타일을 좋아하는 이유는 사람들의 선호하는 음악 에 기인하는 기능과는 불일치하여 음악 선호도의 이론적 발달 모델이 필요하다고 하였다. 이처럼 평소 자신이 좋아한다고 생 각한 특정 음악에 대한 확대 해석으로 장르에 대한 인식 오류 를 일으킬 수 있음을 배제할 수 없다.

\section{본 연구의 한계 및 후속연구 제안}

본 연구에서는 배경음악에 따른 청자의 주의집중력을 알아 보는 초기 연구로서 다음과 같은 한계점을 갖고 있다. 첫째, 다 양한 장르가 혼합된 국내 음악의 트렌드로 인해 장르 분류의 모호함이 있을 가능성이 있다. 정통 장르를 찾아보기 힘든 최 근 국내 대중음악 상황을 고려해 보았을 때, 음악 선호도 설문 지 작성 시 장르에 대한 개인의 기준이 달랐을 것으로 사료된 다. 그룹 음악 선정에 있어서는 록/발라드 혹은 댄스/발라드와 같은 혼합된 장르의 곡을 배제하였지만, 음악 선호도 설문지 작성 시 장르에 대한 구체적인 설명과 예시를 추가하였다면 보 다 더 정확한 결과를 기대할 수 있을 것이다. 둘째, 배경음악으 로서의 역할을 제대로 수행하지 못했을 가능성이 있다. 음악 장르와 특정 음악의 정서, 각성에 대한 수치화된 과학적 분석 은 부재하다. 장르 선호도 조사를 통해 정서와 각성에 대해 보 완하였지만, 각성이라는 정신적 요소를 높고/낮음이라는 음악 요소와 구조에 대한 해석적 측정 혹은 정서적 각성이라는 개인 적 측정으로는 음악이 인지적 과제 수행에 미치는 영향에 대한 분석은 과학적 객관성을 갖기 어렵다(Kang, 2013). 따라서 후 속연구에서는 음악 장르와 특정 음악에 대한 청자의 각성과 정 서에 대한 보다 과학적 접근을 시도하여 음악에 대한 각성과 정서를 정량화하며, 장르에 대한 구체적인 정의와 예시를 바탕 으로 연구 대상자에게 음악 장르에 대한 기준을 보완해야 하겠 다. 이를 보완한다면 장르와 선호도의 상호 관련성을 보다 직접 적으로 확인할 수 있을 것으로 사료된다. 또한 음악 내의 어떤 구성 요소가 주의집중력과 수행력에 직접적이고 긍정적인 영 향을 주는지 밝힌다면, 일반인들에게 다양한 환경에서 배경음 악의 적절한 기준을 제시하는 데 좋은 가이드가 될 것이다.

중심 단어 : 배경음악·카페 음악·집중·FAIR 검사·음악효과.

\section{Ethical Statement}

This study was approved by the Institutional Review Board of Hallym University (HIRB-2018-046).

\section{Acknowledgments}

The authors thank to Donghyun Lee, Kyungmi Kim, Teakyu Lee, Seonghyun Ahan for their assistant to collect the data.

\section{Declaration of Conflicting Interests}

There are no conflict of interests. 


\section{Funding}

This work was completed while being supported by Hallym University Research Funds (HRF-202005-005).

\section{Author Contributions}

S.P. and W.H. designed the experiment together. S.P. collected data and C.K. and W.H. analyzed the data. S.P. wrote the draft of the manuscript, and then W.H. revised the manuscript as the corresponding author. All authors discussed at each stage for the manuscript while providing critical comments.

\section{ORCID iDs}

Sihun Park

Woojae Han

https://orcid.org/0000-0001-6085-2107

https://orcid.org/0000-0003-1623-9676

\section{REFERENCES}

Arnold, U., Ludwig, E., Kühn, R., \& Möschwitzer, U. (1994). Analysis of free amino acids in green coffee beans. Zeitschrift für Lebensmittel-Untersuchung und Forschung, 199, 22-25.

Beak, S. H. \& Lee, Y. M. (2016). Relation between music beats and attention by FAIR. Journal of Korea Entertainment Industry Association. 10(4), 17-23.

Biederman, R. \& Pattison, P. (2014). Basic Live Sound Reinforcement: A Practical Guide for Starting Live Audio. Burlington, MA: Focal Press.

Boersma, P. \& Weenink, D. (2013). Praat: Doing Phonetics by Computer. Version 5.3. 51. praat. Retrieved from https://www.fon.hum.uva.nl/praat/.

Cho, D. U., Cho, S. H., Yang, D. Y., \& Yoo, H. S. (2015). Proceedings of symposium of the Korean Institute of Communications and Information Sciences: A Study on the Healing Effect of 20 Male and Female according to the Type of Rain. Jeju: Ramada Plaza Jeju.

Darrow, A. A., Johnson, C., Agnew, S., Fuller, E. R., \& Uchisaka, M. (2004). Effect of preferred music as a distraction on music majors' and nonmusic majors' selective attention. Bulletin of the Council for Research in Music Education, 170, 21-31.

Goudbeek, M., Goldman, J. P., \& Scherer, K. R. (2009). 10th Annual Conference of the International Speech Communication Association: Emotion Dimensions and Formant Position. Brighton, UK.

Hyun, T. S., Choi, M. H., \& Kim, N. D. (2009). An architectural planning of auditorium with regard to the control for echo, sound focus and reverberation time. The Regional Association of Architectural Institute of Korea, 11(1), 117-124.

Jang, S. W. \& Lee, H. C. (2008). The effect of musical genre on mental focusing. The Korean Psychological Association, 1, 262-263.

Kang, K. S. (2013). A study on the effect of music listening on middle school students' attentiveness. Journal of Art Psychotherapy, 9(4), 267-283.

Kim, J. H. (2016). Study on the method of reading poetry from the point of view of individuation-Focused on the poetry of Kim Su-young and Hwang Byung-seung. Soonchunhyang Journal of Humanities. 35(3), 5981.

Kim, K. H., Kim, J. S., Kim, H. B., Kim, H. K., \& Son, W. H. (2004). Apparatus for Increasing and Conservation of Concentration Using Electro- encephalogram Signal, and Method Thereof. Google Patents. Retrieved from https://patents.google.com/patent/KR100779071B1/ko.

Ko, K., Kim, I., Seo, S., \& Lee, C. (2004). A Study on the environmental friendly noise and vibration management method for the construction project. Korean Journal of Construction Engineering and Management, 5(6), 110-117.

Lee, B. L. (2019). Study café. SMWU Literature Association, (7), 196-199.

Lee, H. W., Jeong, D. H., Joo, D. W., \& Lee, J. S. (2016). A study on illumination consequent on attention concentration and brain wave as against color temperature variations. Korean Society of Color Studies, (5), 80-83.

Lee, J. M. \& Park, H. K. (1988). A study on the measurement of job stress (1). Korean Psychological Association: Society and Personality, 4(1), 241-262.

Lee, J. S., Lee, H. W., Kim, H. N., \& Ryu, J. S. (2014). A basic study on physiological response to color stimulation in red, blue, green, and white according to adolescents' attention and concentration. Journal of Korea Society of Color Studies, 28(1), 177-186.

Moosbrugger, H. \& Oehlschläger, J. (1996). Frankfurter AufmerksamkeitsInventar: FAIR [Frankfurt Attention Inventory: FAIR]. Bern: Huber.

Mornhinweg, G. C. (1992). Effects of music preference and selection on stress reduction. Journal of Holistic Nursing: Official Journal of the American Holistic Nurses' Association, 10(2), 101-109.

Nantais, K. M. (1997). Spatial-temporal skills and exposure to music: Is there an effect, and if so, why? (Unpublished master's thesis). University of Windsor, Windsor.

Nielsen, E, G. (2015). The Coffee Shop Effect: Investigating the Relationship between Ambient Noise and Cognitive Flexibility. Western Libraries. Retrieved from https://ir.lib.uwo.ca/etd/3197.

Oh, H. S. (2002). FAIR Attention Test. Seoul: ChungangJeoksung Institute.

Oh, H. S. (2018). The mediating role of self-directedness in adolescent attention deficit, temperament, and violence. Journal of Education and Culture Studies, 24(1), 351-372.

Pêcher, C., Lemercier, C., \& Cellier, J. M. (2009). Emotions drive attention: Effects on driver's behaviour. Safety Science, 47(9), 1254-1259.

Punkanen, M., Eerola, T., \& Erkkilä, J. (2011). Biased emotional preference in depression: Decreased liking of angry and energetic music by depressed patients. Music and Medicine, 3(2), 114-120.

Rauscher, F. H., Shaw, G. L., \& Ky, K. N. (1993). Music and spatial task performance. Nature, 365(6447), 611.

Schäfer, T. \& Sedlmeier, P. (2009a). Does the body move the soul? The impact of arousal on music preference. Music Perception, 29(1), 37-50.

Schäfer, T. \& Sedlmeier. P. (2009b). From the functions of music to music preference. Psychology of Music, 37(3), 279-300.

Speer, S. (2011). The effect of background music, speech and silence on office workers' selective attention (Unpublished master's thesis). Florida State University, Tallahassee, FL.

Thompson, W. F., Schellenberg, E. G., \& Husain, G. (2001). Arousal, mood, and the Mozart effect. Psychological Science, 12(3), 248-251.

Tze, P. \& Chou, M. (2010). Attention drainage effect: How background music effects concentration in Taiwanese college students. Journal of the Scholarship of Teaching and Learning, 10(1), 36-46.

Wilson, T. L. \& Brown, T. L. (1997). Reexamination of the effect of Mozart's music on spatial-task performance. The Journal of Psychology, 131(4), 365-370. 